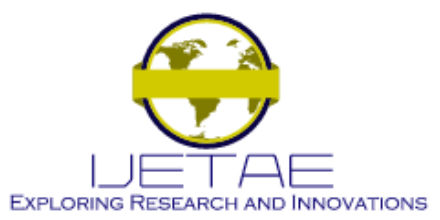

International Journal of Emerging Technology and Advanced Engineering

Website: www.ijetae.com (ISSN 2250-2459, ISO 9001:2008 Certified Journal, Volume 10, Issue 10, October 2020)

\title{
Atmospheric Corrosion Influence in the Manufactured Processes of a Seafood Industry Located in Ensenada, Mexico
}

\author{
Gustavo López Badilla ${ }^{1}$, Juan Francisco Terrazas Gaynor ${ }^{2}$ \\ ${ }^{1}$ Universidad UNEA, Mexicali, Baja California, México \\ ${ }^{2}$ CETYS Universidad, Mexicali, Baja California, México
}

\begin{abstract}
The atmospheric corrosion presented in indoors of a seafood industry, generated aggressive environments and with this deterioration in steel cans used to can sardine and tuna food, which were corroded in the manufacturing processes of this industry evaluated. Even using metal containers with a special coating to can tuna and sardines and with the exposition of aggressive environments the deterioration of these cans was made, before being used for the container of tuna and sardines in the manufacturing areas. The air pollutants as sulfurs principally, which generated the aggressive environments penetrated through cracks and air conditioning systems to indoors of the seafood industry evaluated in Ensenada, promoting the corrosion process originated. The occurrence of corrosion in the seafood industry evaluated, increased the costs of the manufacturing processes for the necessity of takeoff the deterioration of steel cans corroded used to pack tuna and sardine in $45 \%$ of the steel cans received of an industry of United States, and around $35 \%$ of the steel cans used had to be replaced. This represented a decrease in competitiveness in this industrial company evaluated, presenting economic losses, caused by presence the air pollution of Ensenada, which generated the deterioration in steel cans, being originated principally sulfurs of cars and chloride ions of sea breeze. Recently in this city of the northwest of the Mexican Republic, the indices of air pollutants emitted by the traffic vehicle, are increased and overpass the air quality standards (AQS), determined by the Secretaria de Medio Ambiente y Recursos Naturales (SEMARNAT-Mexico) and the Environmental Protection Agency (EPA-USA). For this reason an analysis of the atmospheric corrosion in indoors of a seafood industry located in Ensenada city, was made to identify the aggressive agents that reacted with the metallic surface of steel cans used to can tuna and sardine, with micro evaluation with technique of Scanning Electron Microscopy (SEM) and nano analysis with Auger Electron Spectroscopy (AES) method. The investigation was made in 2019.
\end{abstract}

Keywords-- Seafood industry, atmospheric corrosion, steel cans, SEM, AES.

\section{INTRODUCTION}

The wide use of steel containers in the seafood industry (SFI), for the canning of tuna and sardines, has been decreased the costs, comparing with the use of containers of other materials such as glass and ceramics, utilized to conserve seafood in good condition for certain periods of time ${ }^{1}$. The mechanical and physicochemical properties of steel help to their use for quick and easy manufacturing process. At present, exist a wide variety of foods conserved in steel cans, but in harsh environments, the steel cans are corroded very fast. Aluminum is also material used due to its better resistance to corrosion, but has been become more expensive by its demand ${ }^{2}$. The company evaluated presented increases the economic losses, because in average in the last three years around $25 \%$ of steel cans used in this seafood industry located in Ensenada city, needed replaced for new steel cans provided from United States. This was for the deterioration caused by the atmospheric corrosion and generated that some metal parts of steel cans came off, being attached to the tuna and sardine can, as is showed in figure 1 , being a health problem to consumers, being able to generate gastrointestinal diseases. The objective of use metal packaging is to, the food reaches to the most remote places of the planet, and its stays for longer times without losing its nutritional properties, established and regulated for health standards by the Mexican Official Standards (NOM) and the World Health Organization (WHO). The difference between using metal cans to glass presents greater advantages for steel cans. In the investigation made in the seafood evaluated of Ensenada city, and is considered marine environment, where was used metallic steel cans, appeared two types of corrosion (principally uniform corrosion in winter and pitting corrosion in summer) ${ }^{3}$. 


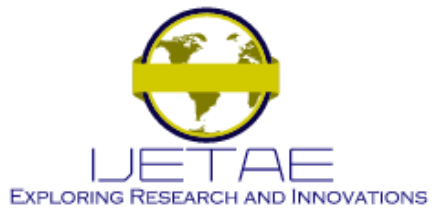

International Journal of Emerging Technology and Advanced Engineering Website: www.ijetae.com (ISSN 2250-2459, ISO 9001:2008 Certified Journal, Volume 10, Issue 10, October 2020)

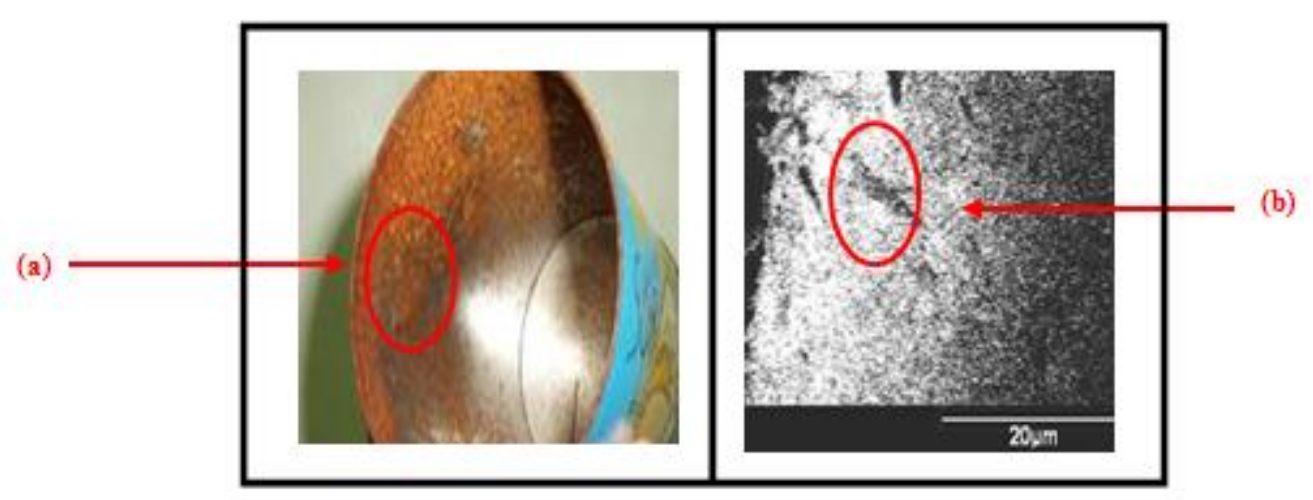

Figure 1 Steel can corroded in internal side (a) and microscopy analysis of tuna with small metallic pieces of steel cans (b) Tuna deteriorate by aggressive environments.

\section{Generation Of Air Pollution In EnSENADA CITY}

The air pollutants, essentially derivate of sulfurs emitted by traffic vehicle in Ensenada, which is a city of Baja California State, where are a lot cars without control of environmental regulations. These cars are sent from the United States to Mexico as scrap cars and are bought by people with low economic resources in this city, where the company is located, in which the investigation of the deterioration of metal containers used to can tuna and sardines was made. Baja California is a state of the Mexican Republic that is a border area with the state of California and allows this type of activity to receive cars that cause large amounts of smog. Car emissions generate air pollutants such as nitrogen oxides, carbon monoxide and especially sulfides, and chloride ions, being the last two chemical agents, which promoted most rapidly the atmospheric corrosion and with it the deterioration of the metal containers used to can tin and sardine in this northwestern region of Mexico.

\section{Sardine and tuna food properties}

The sardine is a blue fish with good source of omega3 , helping to lower cholesterol and triglycerides, and increase blood flow, decreasing the risk of atherosclerosis and thrombosis. Due to these nutrition properties, it's widely consumed in Mexico; because it contains vitamins B12, niacin and B1, and use its energy nutrients (carbohydrates, fats and proteins) as a good diet. This food is important in the biological processes as the formation of red blood cells, synthesis of genetic material and production of sex hormones. Tuna is an excellent food with high biological value protein, vitamins and minerals. It has minerals such as phosphorus, potassium, iron, magnesium and sodium and vitamins $\mathrm{A}, \mathrm{D}, \mathrm{B}, \mathrm{B} 3$ and $\mathrm{B} 12$, which are beneficial for care of the eyes and also provides folic acid to pregnant women.
Sardine and tuna contains fats rich in omega-3, being ideal for people who suffer from cardiovascular disease ${ }^{4}$. Others seafood products considered of the SFI in Mexico are fish, crab and clams principally.

\section{Corrosion and competitiveness in the sea food industry}

The investigation showed a rapid deterioration of steel cans used to pack tuna and sardines in a seafood industry evaluated and located in the Ensenada city, causing a great negative effect on competitiveness of the company, due to the fact that many metal containers were replaced to pack seafood, by the presence of atmospheric corrosion $^{5}$. This concerned to owners, manager and specialized people, because the addition of metallic cans increases the costs, generating economic losses.

\section{Climatic factors}

Climatic parameters, principally the relative humidity (RH) and temperature, in addition with the air pollutants, were factors in the deterioration of steel cans, because generate in winter a complete thin layer in the metallic surfaces of steel cans, even with the coatings used in the steel cans, causing uniform corrosion. In summer generates some thin layers in certain zones of the metallic surfaces of steel cans, originating deterioration in any places of metallic surfaces, causing pitting corrosion. Some scientists of other countries that analyze the atmospheric corrosion comment that the atmospheric corrosion damage very fast steel cans used in the seafood industry installed in coastal environments ${ }^{6}$. These Scientifics, consider that the grade of deterioration of metallic cans is due to the corrosivity levels (CL), originated by drastic changes in the humidity and temperature in certain times of the year. Managers and technicians of companies and people of health institutions in Mexico are concerned, by presence of both types of corrosion in steel cans, for the presence of atmospheric corrosion6. 


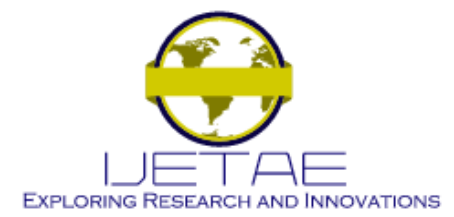

\section{International Journal of Emerging Technology and Advanced Engineering Website: www.ijetae.com (ISSN 2250-2459, ISO 9001:2008 Certified Journal, Volume 10, Issue 10, October 2020)}

\section{Effect of Santa Ana winds in the climatic factors}

The presence of Santa Ana Winds (SAW) in the period from October to April of each year in the Ensenada city, originated drastic variations of humidity and temperature7 and in combination with sulfur and chlorides ions, leaded to the generation of atmospheric corrosion and the deterioration of steel cans ${ }^{8}$. This phenomenon changed conditions the climatic in indoors of the seafood industry evaluated, and decreased very fast in summer, the relative humidity $(\mathrm{RH})$ from $70 \%$ to $30 \%$ and the temperatures increased from $15^{\circ} \mathrm{C}$ to $30^{\circ} \mathrm{C}$. Also, was increased in winter, rapidly the $\mathrm{RH}$ from $40 \%$ to $80 \%$ and decreased the level of temperature from 25 ${ }^{\circ} \mathrm{C}$ to $10{ }^{\circ} \mathrm{C}$, affecting the physiochemical properties of steel cans ${ }^{9}$. With the fast variations, a thin film of moisture is formed that in combination with air pollutants begin the corrosion process in some zones of the metallic containers presenting bad appearance in internal and external of steel cans ${ }^{10}$. The Santa Ana Winds are from the Santa Ana, California zone in the southwest of United States near of the Los Angeles, California.

\section{Air Pollution}

Among the air pollutants emitted by car and formed in the atmosphere, the SO2 was a special importance in the generation of atmospheric corrosion, because of its direct impact in the corrosion rate (CR) of steel cans exposed to the atmosphere of indoors of the seafood industry evaluated $^{2}$. An important feature is that SO2 is more soluble than oxygen, which caused very fast the corrosion phenomena, and occurred at very low concentrations of $\mathrm{SO}_{2}$ in the atmosphere. Also this process was affected by moisture, which were generated the values of $\mathrm{RH}$, causing the formation of thin films in the metallic surface of metallic cans used to conserve sardine and tuna, causing the deterioration of the container $^{11}$. This was very important, as atmospheric studies based on analytical chemistry techniques and high software that determine the composition of the atmosphere and, the effect of corrosivity levels in indoors and outdoors of the food industry. The variations in the climate levels, contributed to accelerate the corrosion rate, being very relevant in the deterioration of steel cans, evaluating the most important of these substances that were present in the atmosphere at levels higher than those expected in thermodynamic equilibrium with nitrogen, oxygen, carbon dioxide and water vapor ${ }^{12}$.

\section{ATMOSPHERIC CORROSION}

The composition of this atmospheric pollution was controlled by a series of kinetic mechanisms and encompassed a complex combination of chemical, physical and biological agents ${ }^{13}$.
Variations of climate factors as humidity and temperature and concentration levels of air pollutants as chlorides ions and sulfurs deteriorated the steel cans used to can tuna and sardine. Regarding its toxicity, air pollutants produced harmful effects in materials, damaging painted surfaces and metallic structures of metallic cans used to conserve seafood ${ }^{14,15}$. This implied, therefore, the need to measure the level concentrations of various pollutants dispersed into the atmosphere. This was achieved using the appropriate techniques and equipments to determine the corrosivity levels in the indoor of the sea food industry evaluated ${ }^{16}$. Was used other method with mathematical models of dispersion of aggressive pollutant gases in a determined area, and their effect in the generation of corrosion in food containers ${ }^{17}$. The correlation between the principal air pollutants mentioned above, generated high corrosion rate, being the responsible of the tarnishing of steel cans with the drastic changes of humidity and temperature by the presence of Santa Ana winds, increasing the corrosion rate of metallic food containers.

\section{SEM AND AES TECHNIQUES}

Some pieces of steel cans were evaluated by the microscopy and spectroscopy techniques as Scanning Electron Microscopy (SEM) and Auger Electron Spectroscopy (AES) to determine the air pollutants that react with the metallic surface exposed in the manufacturing process and warehouses in indoor zones of the food industry. The incident electrons used to analyze the metallic surface of steel cans was generated by the SEM inside the chamber. The quantitative and qualitative chemical analysis information was obtained using the energy disperse x-ray (EDS) with the SEM ${ }^{14}$. The images in SEM were created by the incident beam of electrons in the raster pattern of the sample's surface. From the complete area of metallic probes a small fraction of $1 \mathrm{~cm}^{2}$ was cut, to analyze in the SEM equipment and to introduce to the chamber in the Auger Electron Spectroscopy (AES) equipment, to be evaluated with the AES technique using rubber gloves in both cases $^{15}$. To analyses and determine the air pollutants added to steel cans in the surface was used the SEM technique and to analyze in layers down of the surface, was utilized the AES technique to determine the corrosion products in steel cans used in the seafood industry. Then with the AES technique, was evaluated some pieces were installed in the AES chamber and then was introduced to an ultrahigh vacuum (UHV) system to made a nano evaluation. The examination in the vacuum chamber required of two steps: use a mechanical oil pump to decrease the room pressure to 50 militorr and the use of a turbomolecular pump together with the mechanical pump, to reduce the pressure to 1 nanotorr ${ }^{16}$. 


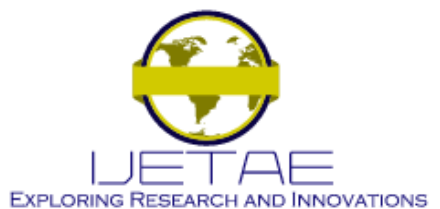

International Journal of Emerging Technology and Advanced Engineering Website: www.ijetae.com (ISSN 2250-2459, ISO 9001:2008 Certified Journal, Volume 10, Issue 10, October 2020)

With this technique was knew in detail, quickly and with a good precision, the structural form and location of corrosion, which will determined the type of corrosion and knotweed the techniques protection for the metals analyzed $^{17}$. AES analysis was performed in Bruker Quantax and ESCA / SAM 560 models, and the bombarding were obtained when samples with a beam of electrons with energy of $5 \mathrm{keV}$ we made a clean surface of metal specimens analyzed with an ion beam with energy Argon-Ar $+5 \mathrm{keV}$ and current density of $0.3 \mathrm{uA} /$ $\mathrm{cm}^{3}$ to remove $\mathrm{CO}^{2}$ from the atmosphere ${ }^{18}$. Sputtering process was made to know and the type of film formed in the metallic surface of steel probes is continues as uniform corrosion or by points separated as pitting corrosion. The AES method was an effective analytical method used to determine the process of corrosion. These techniques were used for their confidence level compared with other techniques.

\section{EXPERIMENTAL METHODS}

Some steel cans used as a small metallic pieces to exposed to aggressive environments generated by the variations of relative humidity by the presence of Santa Ana winds and the concentration levels of $\mathrm{Cl}^{-}$and $\mathrm{SO}_{2}$ principally in indoor of the seafood evaluated. The steel cans were exposed by one year by monthly periods in the 2010 year $^{18}$. To determine the percentage of the concentration levels of the air pollutants measured by the gases analyzer LANCOM III-AMETEK and that react with the metallic surfaces of steel cans, are used the SEM and AES techniques. Also was obtained the principal climatic factors as relative humidity and temperature by a hygrometer with a thermometer integrated. And was mentioned only the solar radiation and wind direction and speed to be considered in future studies to determine with more specifications the effect of climatic factors in the origin of atmospheric corrosion ${ }^{19}$. The same case occurs to the air pollutants with the other polluted agents with a minimum effect in the generation of atmospheric corrosion.

\section{RESUlTS AND DISCUSSIONS}

The wide use of steel packaging in the food industry, from their initial experimental process, has been very supportive to keep food in good conditions during certain periods of time, with advantages over other materials such as glass, ceramics, iron and tin. The mechanical and physicochemical properties of steel help to their use for quick and easy manufacturing process.
At present exist a wide variety of foods conserved in steel cans, but in harsh environments, they corrode ${ }^{10}$. With metal packaging, the food reaches to the most remote places of the planet, and its stays for longer times without losing its nutritional properties, established and regulated for health standards by the Mexican Official Standards (NOM) and the WHO. In coastal areas, where some food companies operate, using steel cans, the AC appears frequently. Even with the implementation of techniques and methods of protection and use of metal and plastic coatings, corrosion is still generated, being lower with the use of plastics ${ }^{2}$.

\section{INFLUENCE OF CLIMATIC FACTORS IN CR}

Variations of $\mathrm{RH}$ in the range from $25 \%$ to $75 \%$ and temperatures from $5{ }^{\circ} \mathrm{C}$ to $30^{\circ} \mathrm{C}$, and the concentration levels of air pollutants such as sulfides and chlorides, which exceeded the permitted levels of the AQS, which increased the corrosion process. The investigation was made principally in summer and winter, being a comparative analysis of the generation of both corrosion types mentioned above ${ }^{9}$. The evaluations considered too, variations of humidity and temperatures that is typical of this city during certain seasons of the year. Sometimes, is necessary monitoring and control principally the RH, to hold the adequate range and avoid the generation of corrosion. Exposition to $\mathrm{SO}_{2}$ indicates mores damage, compared with the effect of the chlorides in the metallic surface of steel probes. The maximum CR representing the deterioration with steel exposed to $\mathrm{SO}_{2}$ was in winter for the high concentration levels of $\mathrm{RH}$ and the minimum was in summer. The major effect of $\mathrm{Cl}^{-}$on the deterioration of metallic surface occurred in winter and the minimum was in spring, same with the exposition of $\mathrm{SO}_{2}$.

\section{CORROSION RATE ANALYSIS}

In this study the CR in steel cans at one year of analysis was low, but affect to the coating films. In the summer season (June to August), at beginning of the evaluation, the range of $\mathrm{CR}$ was from $5 \mathrm{mg} . \mathrm{m}^{2} /$ year to $130 \mathrm{mg} . \mathrm{m}^{2} /$ year (Figure 2). The same case occurred in the winter season (November to January), where the CR was less than $10 \mathrm{mg} \cdot \mathrm{m}^{2} /$ year to $230 \mathrm{mg} \cdot \mathrm{m}^{2} /$ year (Figure 3). As mention the Pilling-Bedworth equation ${ }^{19}$, the CR represented a parabolic curve, and a film was formed almost full in the metallic surface with isolated zones where was occurred the braked of the film. 


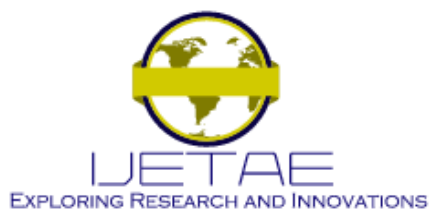

International Journal of Emerging Technology and Advanced Engineering Website: www.ijetae.com (ISSN 2250-2459, ISO 9001:2008 Certified Journal, Volume 10, Issue 10, October 2020)

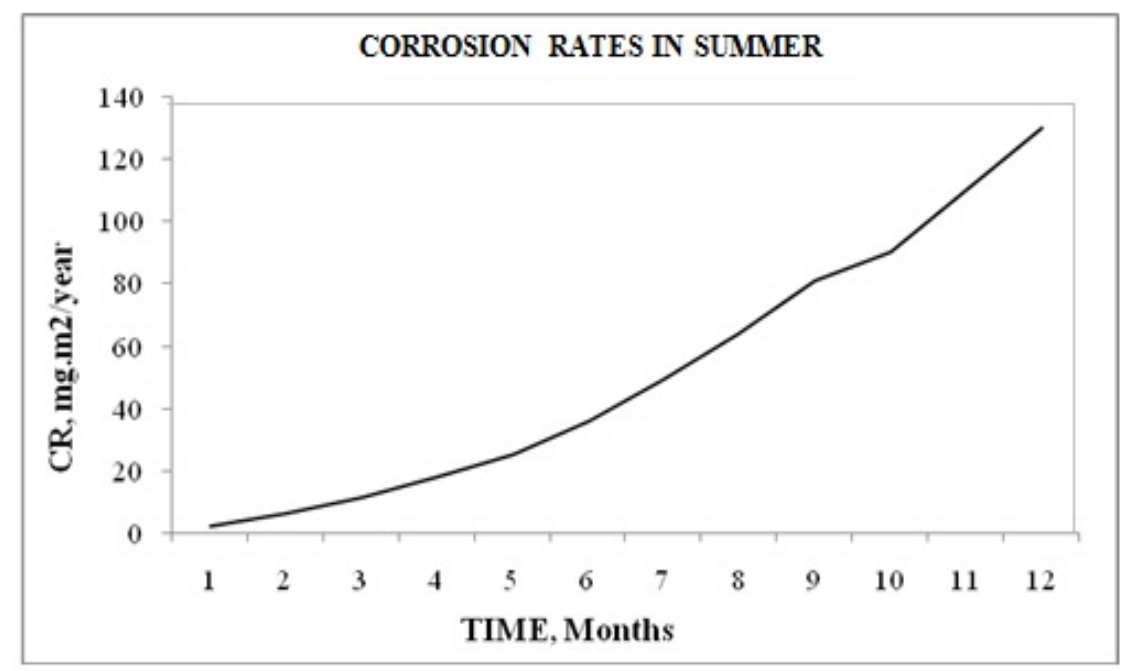

Figure 2 Corrosion rates of steel cans in summer in Ensenada (2019).

Corrosion Rates In Summer Corrosion Rates In Winter

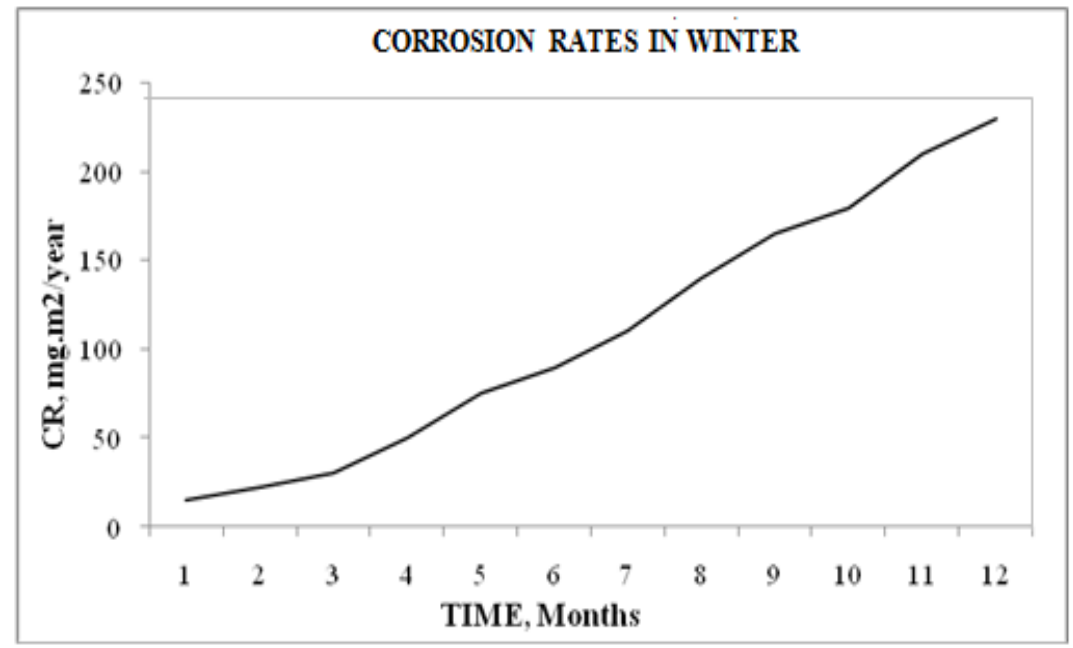

Figure 3 Corrosion rates of steel cans in winter in Ensenada (2019).

\section{Deterioration of steel cans}

Ranges of $\mathrm{RH}$ and temperature were higher than $80 \%$ and $35^{\circ} \mathrm{C}$ during the year in Ensenada and with a minimum of $35 \%$ and $25^{\circ} \mathrm{C}$ in the periods of heat winds, and maximum of $85 \%$ and $15^{\circ} \mathrm{C}$ in the rest of the year in Ensenada. Levels of humidity and temperature bigger than $75 \%$ and $35{ }^{\circ} \mathrm{C}$ accelerated the corrosion rate. In summer the corrosion rate was higher after one year. For temperatures in the range from $25^{\circ} \mathrm{C}$ to $35^{\circ} \mathrm{C}$, and $\mathrm{RH}$ level of $35 \%$ to $75 \%$, the $\mathrm{CR}$ was very high. Furthermore, in winter, at temperatures around $10^{\circ} \mathrm{C}$ to $20^{\circ} \mathrm{C}$ and $\mathrm{RH}$ levels from $25 \%$ to $85 \%$, water condensates on the metal surface and the corrosion rate increased very fast.
Productive levels in the seafood industry of the northwest of Mexico

The deterioration of materials caused a negative impact in the productive levels in the industrial plant evaluated. This was represented in tables 1 and 2 with a detailed evaluation with spring, summer, autumn and winter seasons, where are showed in table 1 the manufactured products as good and defective in an evaluation by season of the year and it relation with the productive yielding of industrial equipment of the company and the climatic and pollution factors analyzed. The spring season was the season with major products manufactured with good acceptation of quality by the customers. 


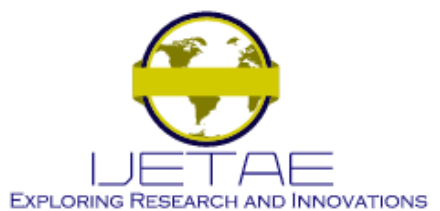

International Journal of Emerging Technology and Advanced Engineering Website: www.ijetae.com (ISSN 2250-2459, ISO 9001:2008 Certified Journal, Volume 10, Issue 10, October 2020)

Then was following the autumn, summer and finally the winter periods. Then was showed the productive yielding by equipment, indicating the best seasons of yielding in spring, autumn, summer and winter respectively. Climatic and pollution factors were important aspects in the deterioration of materials and with this were difficult to make the manufacturing operations in the industrial equipment and these parameters generate a negative effect in the productive levels.
Also in table 2, the analysis of economic payments for warranty to customers and to the workers to make rework activities was made. This indicated that the payments of warranty were higher than the workers by rework and the months of winter were the periods with major payments in percentages.

Table 1.

Analysis of productivity levels correlated with climatic and pollution factors (2019)

\begin{tabular}{cccccccccccc}
\hline Periods & \multicolumn{4}{c}{ MP, \% } & \multicolumn{4}{c}{ PYE (\%) } & \multicolumn{4}{c}{ Climatic factors } & \multicolumn{2}{c}{ Pollution factors } \\
& Good & Defective & E1 & E2 & E3 & E4 & E5 & RH, \% & T, ${ }^{\circ} \mathrm{C}$ & SO $_{2}$, ppm & NO $_{\mathbf{X}}, \mathrm{ppm}$ \\
Spring & 60 & 40 & 37 & 34 & 36 & 35 & 34 & 73 & 23 & 0.44 & 0.057 \\
Summer & 54 & 46 & 30 & 31 & 32 & 33 & 30 & 80 & 37 & 0.42 & 0.047 \\
Autumn & 58 & 42 & 36 & 33 & 35 & 31 & 33 & 70 & 28 & 0.44 & 0.046 \\
Winter & 40 & 60 & 31 & 35 & 35 & 36 & 33 & 87 & 13 & 0.69 & 0.075 \\
\hline
\end{tabular}

MP. Manufactured products; PYE. Productive yielding equipment: E1, E2, E3, E4, E5. Equipment 1, 2, 3, 4 and 5; RH. Relative Humidity, T. Temperature, $\mathrm{SO}_{2}$ (Sulfur dioxide), $\mathrm{NO}_{\mathrm{X}}$ (Nitrogen oxides)

Table 2.

Analysis of economic payments by warranty by health problems caused by the degradation of steel cans correlated with climatic and pollution factors (2019)

\begin{tabular}{cccccccccccc}
\hline Months & \multicolumn{3}{c}{ EP, \% } & \multicolumn{4}{c}{ LTR min } & \multicolumn{3}{c}{ Climatic factors } & \multicolumn{2}{c}{ Pollution factors } \\
& W & WS & E1 & E2 & E3 & E4 & E5 & RH, \% & T, ${ }^{\circ} \mathrm{C}$ & $\mathrm{SO}_{2}, \mathrm{ppm}$ & $\mathrm{NO}_{\mathrm{X}}, \mathrm{ppm}$ \\
January & 14 & 10 & 899 & 789 & 797 & 844 & 865 & 88 & 15 & 0.66 & 0.056 \\
February & 13 & 11 & 778 & 792 & 802 & 787 & 789 & 83 & 23 & 0.52 & 0.058 \\
March & 12 & 9 & 768 & 777 & 767 & 778 & 756 & 75 & 19 & 0.48 & 0.057 \\
April & 14 & 8 & 690 & 698 & 678 & 690 & 677 & 72 & 27 & 0.47 & 0.048 \\
May & 15 & 10 & 617 & 589 & 599 & 593 & 599 & 69 & 29 & 0.46 & 0.045 \\
June & 16 & 8 & 655 & 643 & 702 & 697 & 688 & 79 & 32 & 0.45 & 0.039 \\
July & 16 & 11 & 766 & 780 & 803 & 805 & 814 & 84 & 36 & 0.46 & 0.047 \\
August & 14 & 12 & 802 & 802 & 890 & 888 & 898 & 86 & 39 & 0.47 & 0.052 \\
September & 13 & 8 & 777 & 784 & 799 & 797 & 797 & 80 & 35 & 0.57 & 0.058 \\
October & 17 & 9 & 766 & 767 & 768 & 743 & 744 & 76 & 29 & 0.59 & 0.062 \\
November & 19 & 10 & 785 & 799 & 807 & 807 & 804 & 78 & 25 & 0.62 & 0.066 \\
December & 20 & 11 & 813 & 845 & 867 & 846 & 888 & 89 & 12 & 0.68 & 0.082 \\
\hline
\end{tabular}

PEP. Percentage of economic payments by the company evaluated by warranty (W) and rework as a worker's salary by deteriorated materials (WS) compared with the economic gains of the company; LT. Lost Time for rework in equipment: E1, E2, E3, E4, E5. Equipment 1, 2, 3, 4 and 5; RH. Relative Humidity, T. Temperature, $\mathrm{SO}_{2}\left(\mathrm{Sulfur}_{\text {dioxide}}\right), \mathrm{NO}_{\mathrm{X}}$ (Nitrogen oxides)

\section{SEM AND AES ANALYSIS}

The corrosion products in the internal of container were emerged from the steel cans deteriorate, as showed in figure 4. Figures $4 \mathrm{a}$ show SEM images at $500 \mu \mathrm{m}$ (points 1 and 2 ), the $4 \mathrm{~b}$ at $5 \mu \mathrm{m}$ (from point 1 , which is represented by points $\mathrm{A}$ and $\mathrm{B}$ ) and the Auger spectra is $4 c$, in a period of exposure of eighteen months.
Figure 5 show the SEM images in the external zone, at $500 \mu \mathrm{m}$ (points 1 and 2). In $5 \mathrm{a}$, are showed at $5 \mu \mathrm{m}$ (from point 2 , which is indicated by points $\mathrm{A}$ and $\mathrm{B}$ ) in $57 \mathrm{~b}$, which represents a film broken, and in $5 \mathrm{c}$ the Auger spectra at eighteen months of exposition, in indoor of the seafood industry. The principal corrosion products were rich in chlorides and sulphides in the steel cans evaluated. 


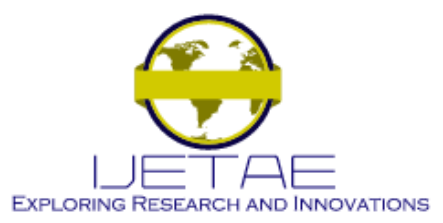

International Journal of Emerging Technology and Advanced Engineering

Website: www.ijetae.com (ISSN 2250-2459, ISO 9001:2008 Certified Journal, Volume 10, Issue 10, October 2020)

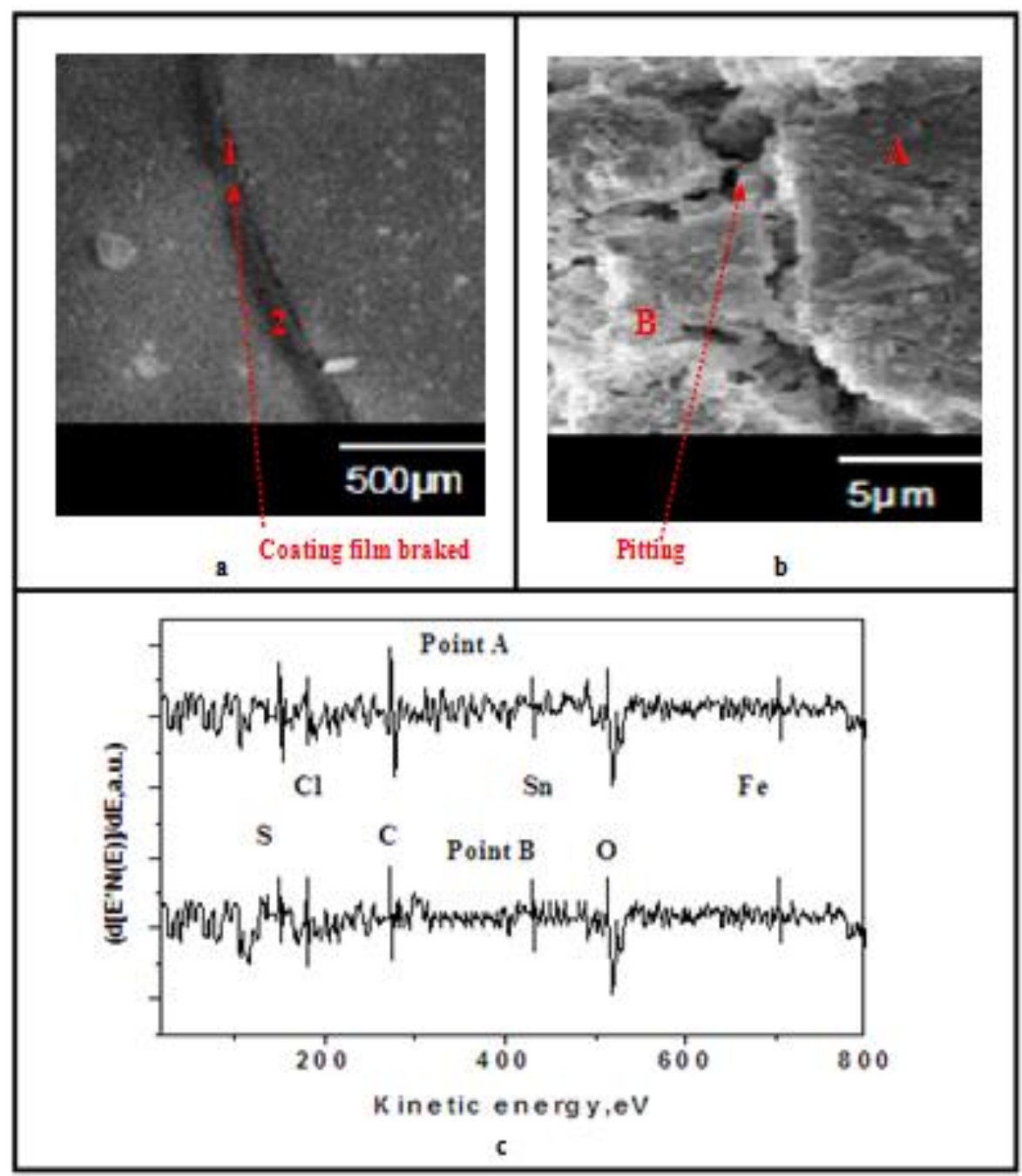

Figure 4 Internal evaluation of atmospheric corrosion in thin pieces of steel cans: (a) SEM 500X, (b) SEM 5X at point 1 and (c) AES analysis of SEM 5X exposed at six months (2019). 


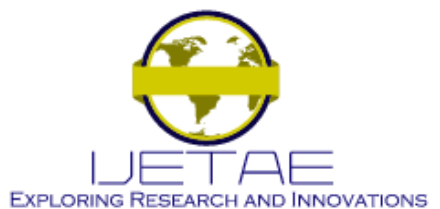

International Journal of Emerging Technology and Advanced Engineering Website: www.ijetae.com (ISSN 2250-2459, ISO 9001:2008 Certified Journal, Volume 10, Issue 10, October 2020)

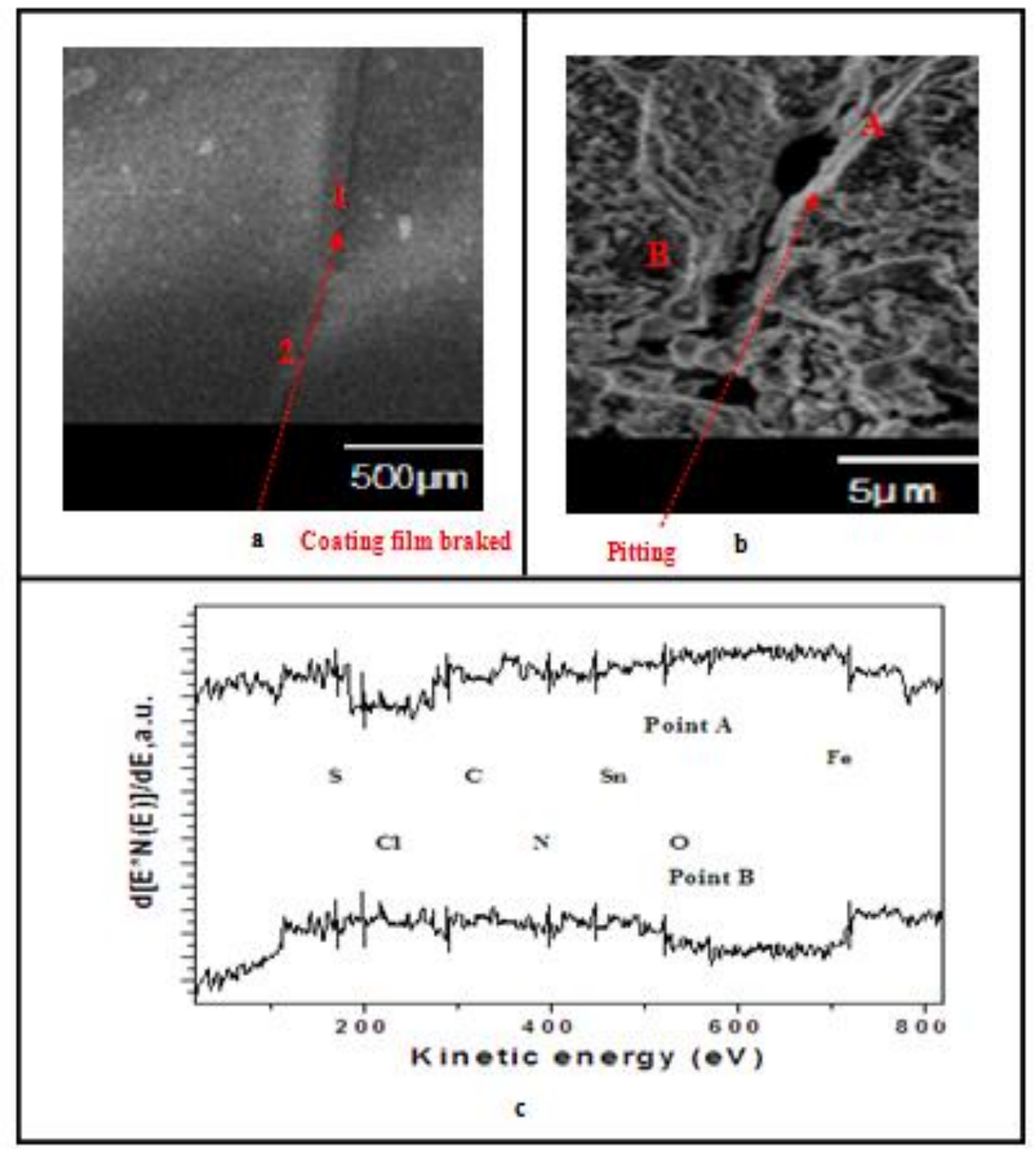

Figure 5 External evaluation of atmospheric corrosion in tin plated steel cans: (a) SEM 500X, (b) SEM 5X at point 1 and (c) AES analysis of SEM 5X exposed at six months (2019).

\section{CONCLUSIONS}

Corrosion is the general cause of the destruction of most of natural materials. Although this destructive force has always existed, no attention has been paid to modern times, with the advancement of technology. Steel production and improved mechanical properties have made it a very useful material, along with these improvements, but still, it is with great economic losses, because $25 \%$ of annual world steel production is destroyed by erosion. At levels of relative humidity (RH) higher than $80 \%$ in this marine environment, is formed a thin film, but when it isn't uniform, sulfurs ad chlorides principally react with the metallic surface and the corrosion occur, appearing isolated black stains. This generates deterioration in steel cans, and it can't be used to conserve sardine and tuna.
Chloride ions and sulfates are from sea breeze and traffic vehicles in this city. This study was made to analyze the corrosivity levels in indoor of the seafood industry and determine if the thin film formed is a protective or not coating, with the corrosion rate, the Pilling-Bedworth relation and the Scanning Electron Microscopy and the Auger Electron Spectroscopy techniques with the sputtering process, which diminish or accelerate the corrosion process, and propose methods to control the atmospheric corrosion. The major corrosion was occurred in cans with tin plate steel cans and the minor in steel cans with plastic coatings, indicating that the material without the tinned process is better to conserve sardine and tuna in good conditions. 


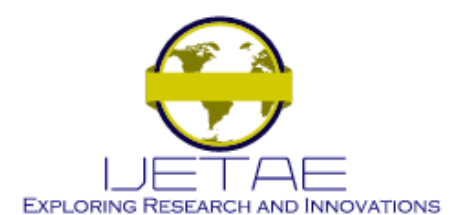

International Journal of Emerging Technology and Advanced Engineering Website: www.ijetae.com (ISSN 2250-2459, ISO 9001:2008 Certified Journal, Volume 10, Issue 10, October 2020)

The two curves in the CR were parabolic representations, indicating, the low interaction of ions in the metallic surface of steel cans, and it generated a protective film in almost the surface, excepting the isolated zones where was braked the films. Microphotographs of SEM show the corrosion products in Ensenada with the light stains of chlorides and the dark tarnishing of sulfates. The gravimetric method presented the maximum loss mass with $208.7 \mathrm{mg} / \mathrm{m}^{2}$.year and the minimum of $56.7 \mathrm{mg} / \mathrm{m}^{2}$.year on the experimental steel rolls probes used to evaluate the internal and external surfaces. The AES analyses show the chemical composition of the corrosion products formed by the reaction of air pollutants with the steel surface in the internal and external cans surfaces. Despite the low concentrations found in these atmospheres, often represent a risk of the deterioration of metallic cans using to conserve sardine and tuna.

\section{REFERENCES}

[1] Altos Hornos de México. (2010). "Acero AHMSA para la industria petrolera y de construcción".

[2] A. Brody, E.R. Strupinsky, L.R. Kline. (2001). "Odor removers. In: Brody A, Strupinsky ER, Kline LR, editors. Active packaging for food applications"; Lancaster, Pa.: Technomic Publishing Company, Inc. p 107-17.

[3] JB Lord. (2008). "The food industry in the United States"; In: Brody AL, Lord J, editors. Developing new food products for a changing market place. 2nd ed. Boca Raton, Fla.: CRS Press. p 123.

[4] FAO. (2010). "Corporate Repository Report".

[5] Sánchez, C; Tesis de Doctorado. (2010). "Análisis de un modelo de competitividad aplicado a las comercializadoras de autos en Mexicali, Baja California, México." Septiembre de 2010.

[6] G. Lopez-Badilla. (2008). "Caracterización de la corrosión en materiales metálicos de la industria electrónica en Mexicali, B.C.", PhD Thesis (Spanish).
[7] G. Lopez-Badilla, B. Valdez-Salas, M. Schorr, R. Zlatev, H Tiznado, G. Soto, W. De la Cruz. (2010). "AES in corrosion of electronic devices in arid in marine environments", AntiCorrosion Methods and Materials.

[8] G. Lopez-Badilla, B. Valdez-Salas, M. Schorr, R. Zlatev, H. Tiznado, G. Soto, \& W. De la Cruz. (2011). "AES in corrosion of electronic devices in arid in marine environments", AntiCorrosion Methods and Materials.

[9] World steel association (WSA). (2011). "Environmental case study, steel food cans".

[10] K.L. Yam, P.T. Takhistov, J. Miltz. (2005). "Intelligent packaging: concepts and applications"; J. Food Sci 70(1):R1-10.

[11] AHRAE; Handbook (1999). "Heating, Ventilating and AriConditioning; Applications"; American Society of Heating, Refrigerating and Air-Conditioning Engineers Inc.

[12] K. Finkenzeller. (2003). "RFID handbook: fundamentals and applications". 2nd ed. West Sussex, U.K.: JohnWiley \& Sons Ltd. 452 p.; 2003.

[13] Annual Book of ASTM Standards. (2000). "Wear and Erosion: Metal Corrosion, Vol. 03.02.

[14] Phillip G. Harrison, Paul Brown. (2003). "External reflection FTIR, ${ }^{31} \mathrm{P}$ MAS NMR and SEM study of the thermal decomposition of zinc(II) bis(O,O'-dialkyldithiophosphates) on 316 stainless steel, Measurement J. pp 34-40, Vol. 1, No, 2.

[15] Clark A. E., Pantan C. G, Hench L. L. (2006). "Auger Spectroscopic Analysis of Bioglass Corrosion Films"; Journal of the American Ceramic Society; Volume 59 Issue 1-2, Pages 37 39; 2006.

[16] Nachay K. (2007). "Analyzing nanotechnology"; Food Tech J. No. 61(1):34-6.

[17] R. Zlatev, B. Valdez, M. Stoycheva, L. Vargas, G. Lopez, M. Schorr. (2009). "Analysis of corrosion in industrial plants of Mexicali"; Simpsoium 16: NACE "Corrosion and Metallurgy"; IMRC 2009, Cancun, Mexico.

[18] H. C. Swart., J. J. Terblans., E. Coetsee, V. Kumar, O. M. Ntwaeaborwa, Dhlamini M.S., J.J. Dolo. (2010). "Auger electron spectroscopy and X-ray photoelectron spectroscopy study of the electron-stimulated surface chemical reaction mechanism for phosphor degradation"; Surface and Interface Analysis; pp. 5663; Vol.3,No 1.

[19] Chunhua X.; Wei G. (2000). Pilling-Bedworth ratio for oxidation of alloys, Materials Research Innovations, ISSN 1432-8917, Vol. 3, No. 4, pp 231-235. 